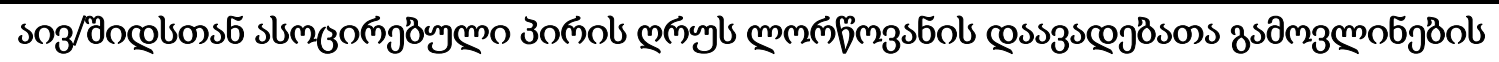

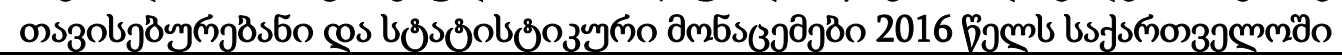

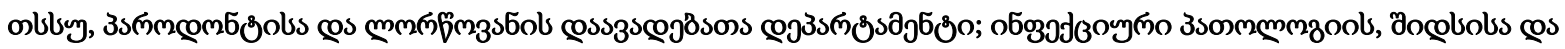

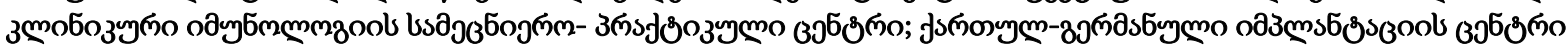
"HBI-dentImplant"

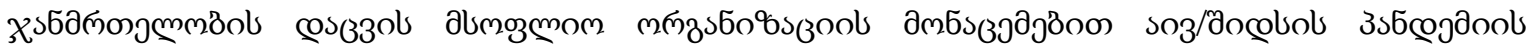

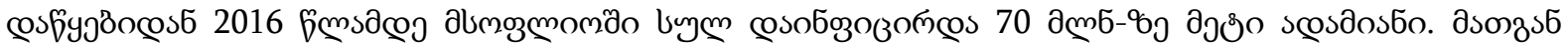

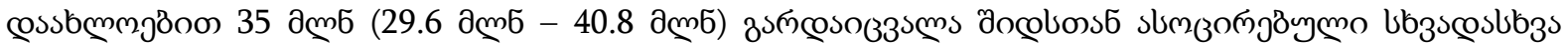

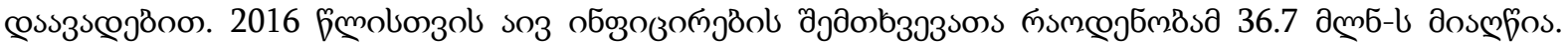

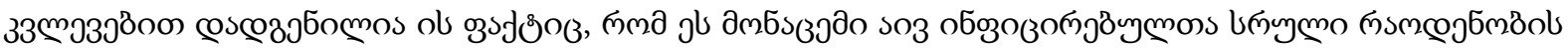

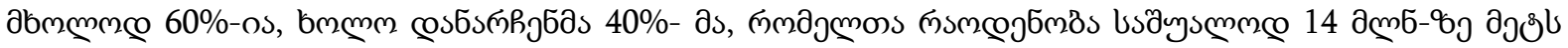

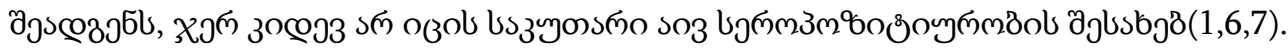

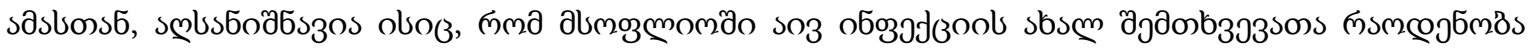

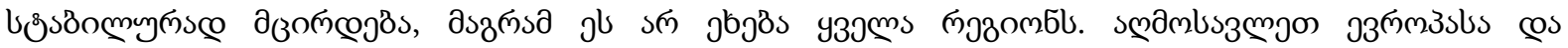

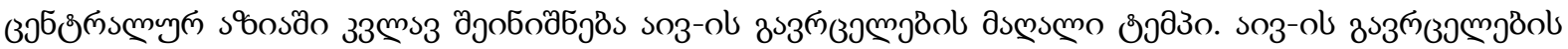

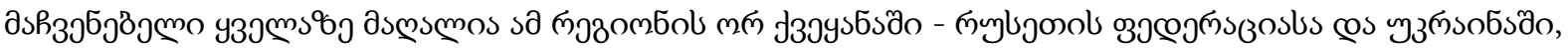

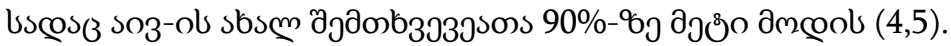

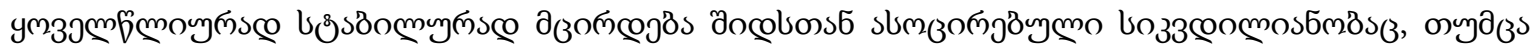

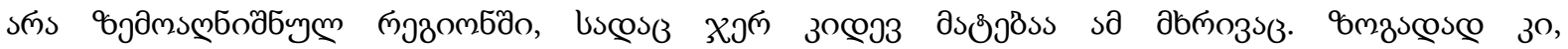

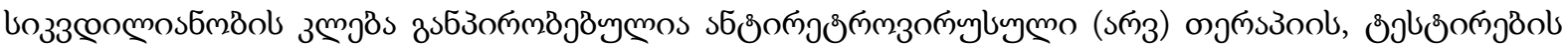

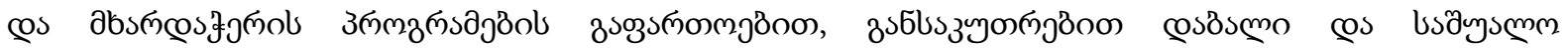
зsббоoss

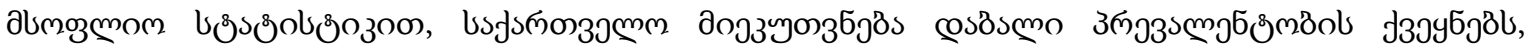

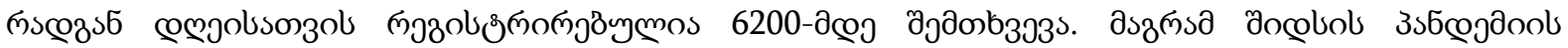

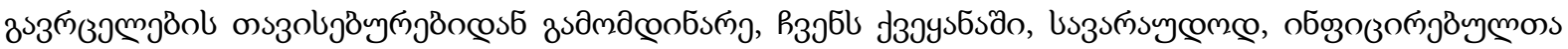

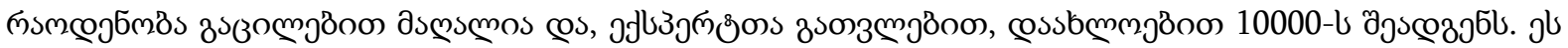

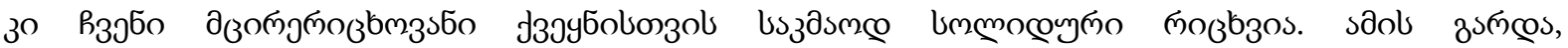

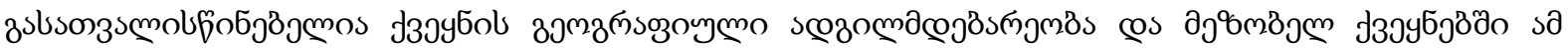

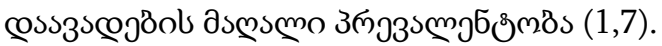

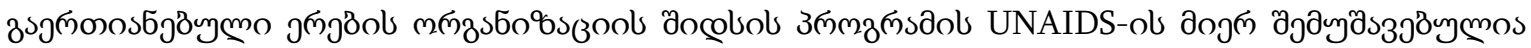

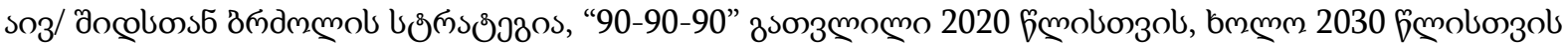

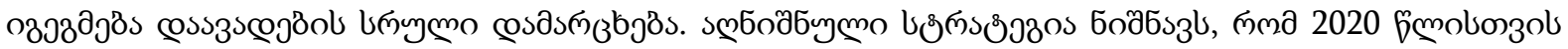

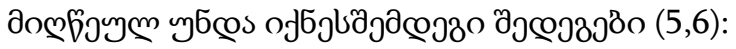

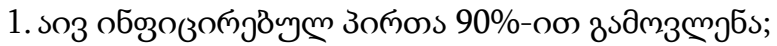

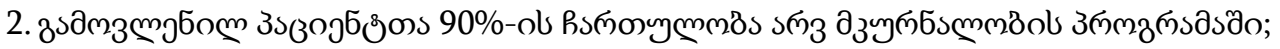

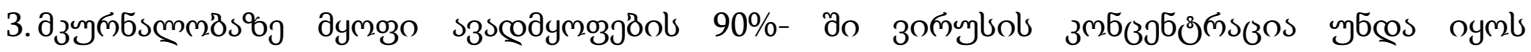

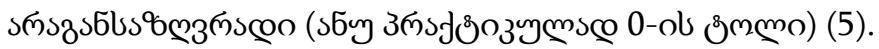

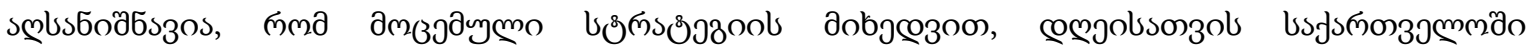

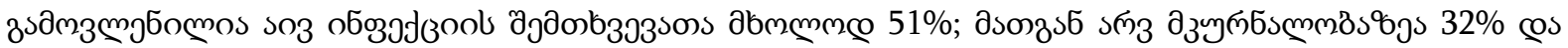

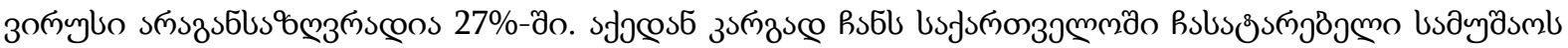

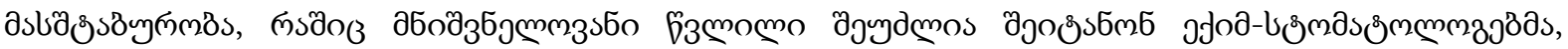

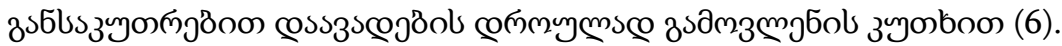

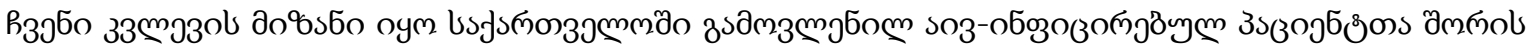

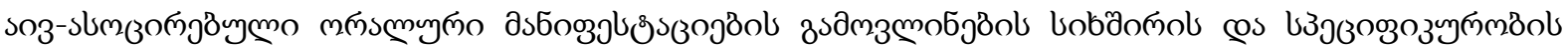
coscojos.

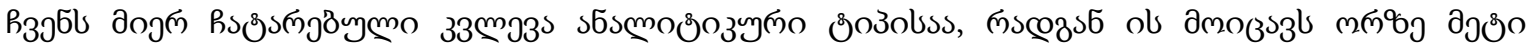

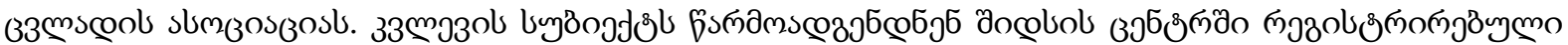
зьзојб 


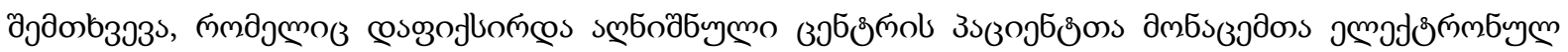

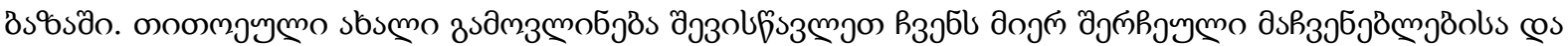

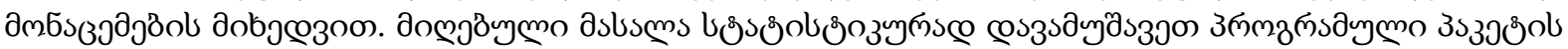
SPSS 22.0 (Statistical Package for the Social Sciences) żdmyjб

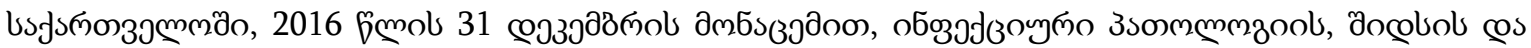

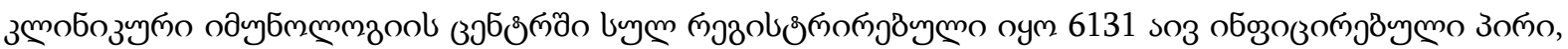
sगjess:

- $2 \operatorname{sas} 3{ }^{\circ} 3^{\circ}-4553(74.26 \% 0.58)$,

- jumo - 1578(25.74\%1.7) (6.7).

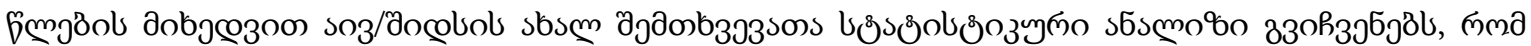

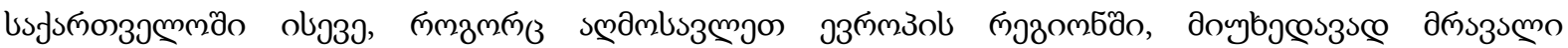

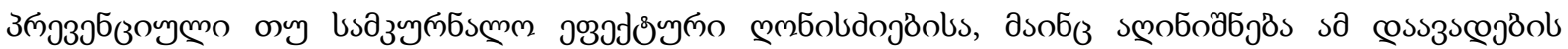

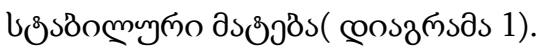

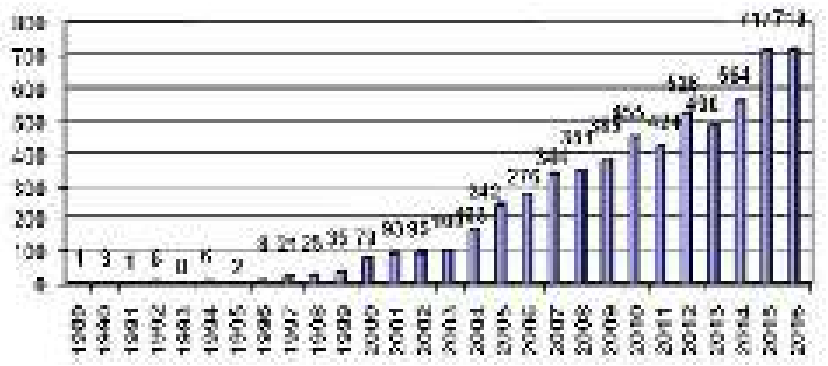

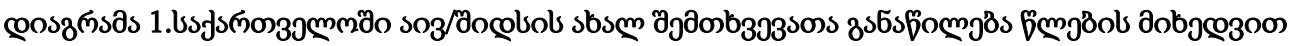

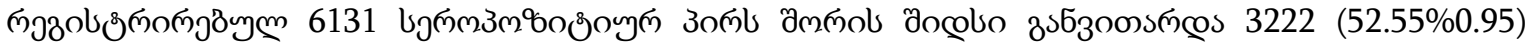

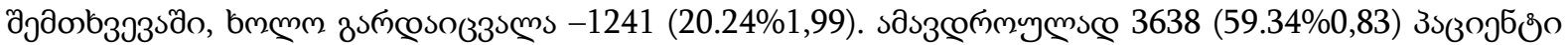

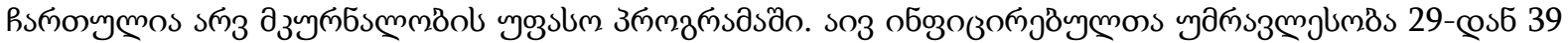

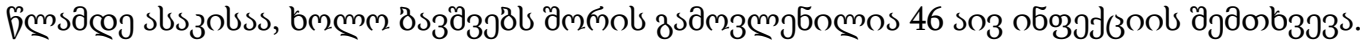

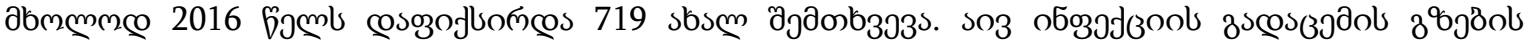
bobə̃ong sbyon:

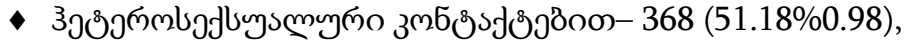

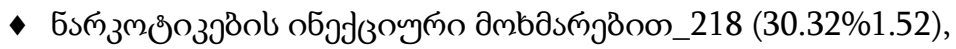

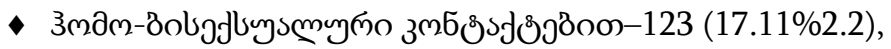

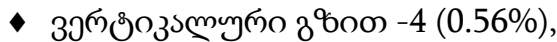

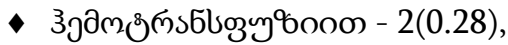

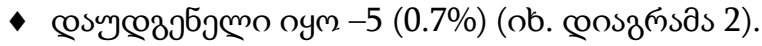
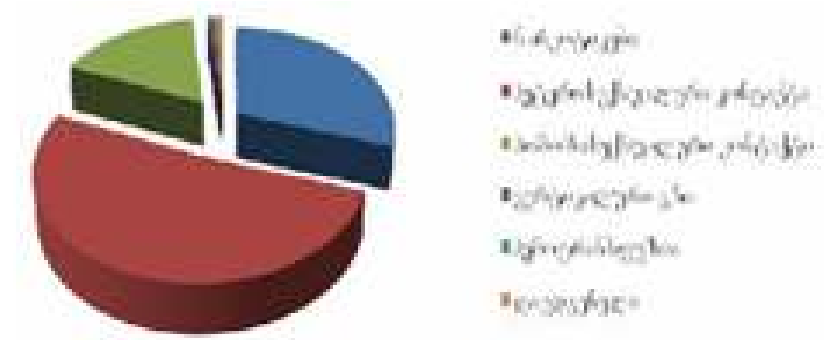

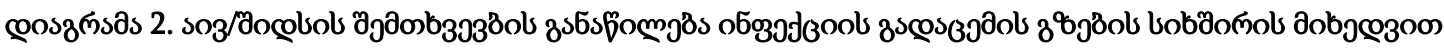

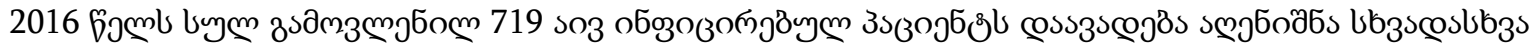
boscoos 6 g:

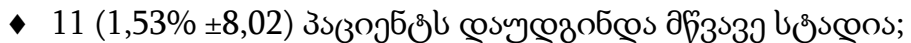

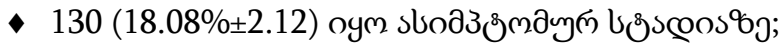

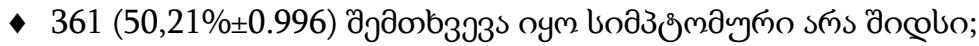




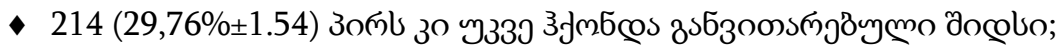

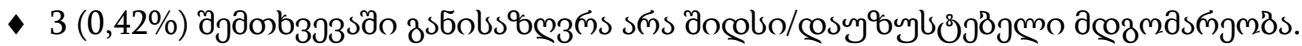

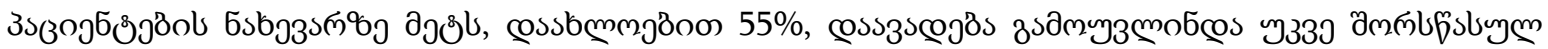
bosscos\%g.

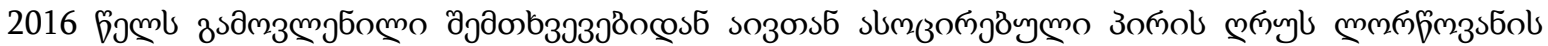

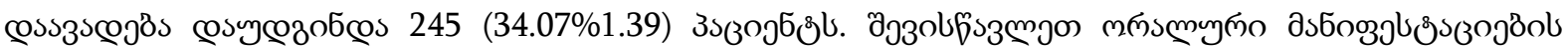

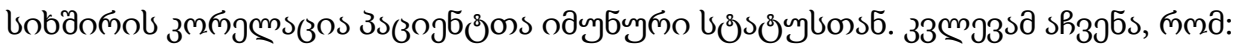

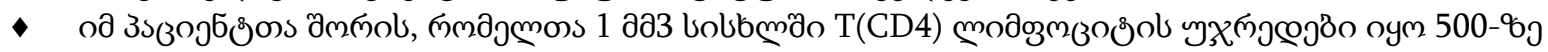

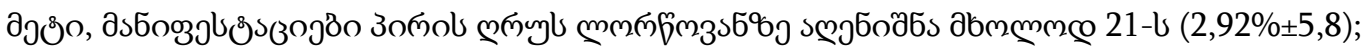

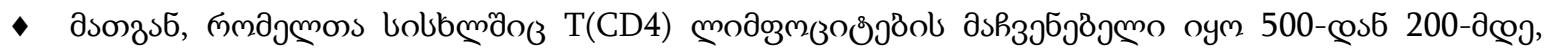

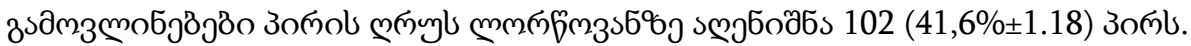

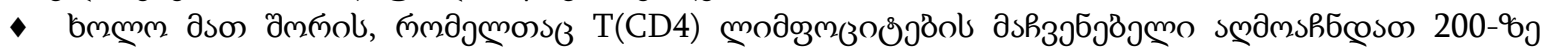

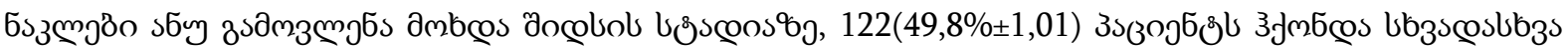

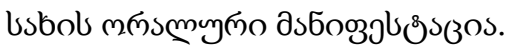

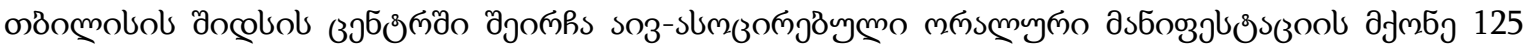

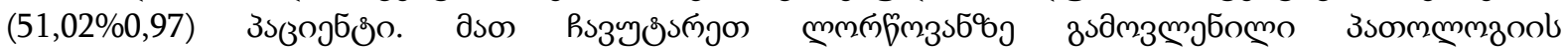

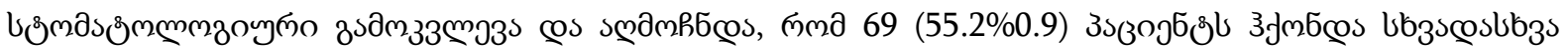

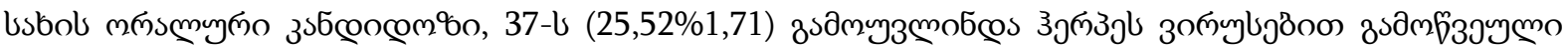

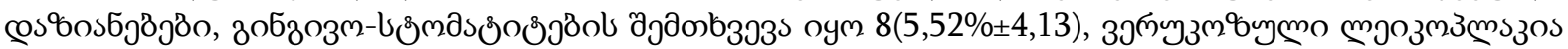

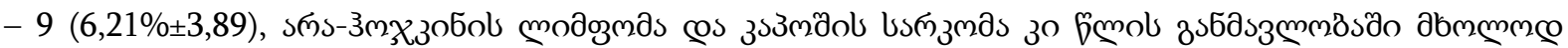

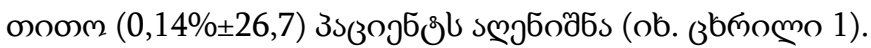

\begin{tabular}{|c|c|}
\hline 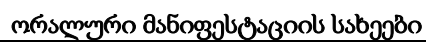 & bobə̃om \\
\hline 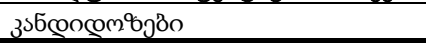 & $69(55.2 \% 0.9)$ \\
\hline 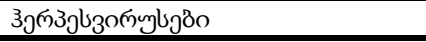 & $37(25,52 \% 1,71)$ \\
\hline 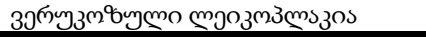 & $9(6,21 \% \pm 3,89)$ \\
\hline 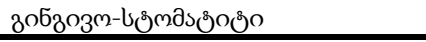 & $8(5,52 \% \pm 4,13)$ \\
\hline 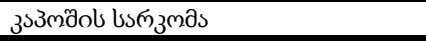 & $1(0,14 \%)$ \\
\hline 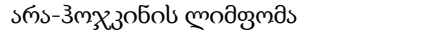 & $1(0,14 \%)$ \\
\hline
\end{tabular}

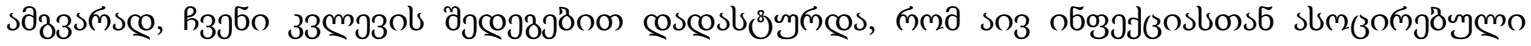

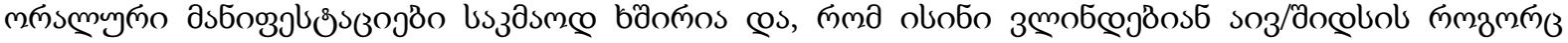

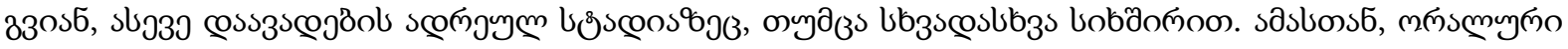

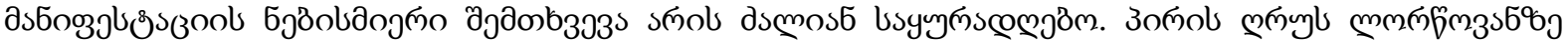

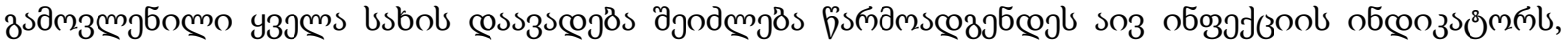

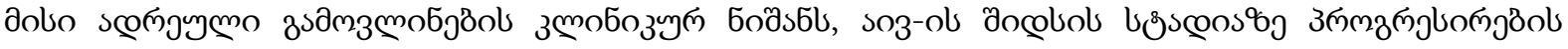

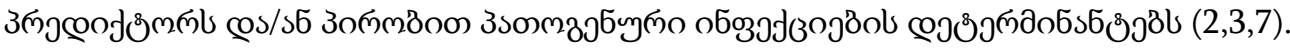

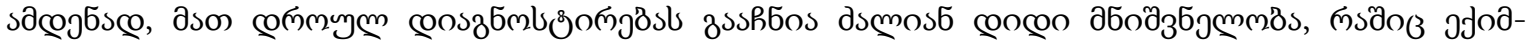

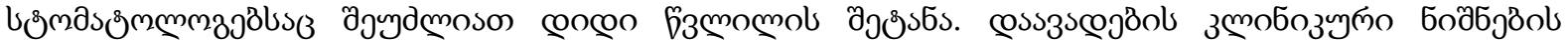

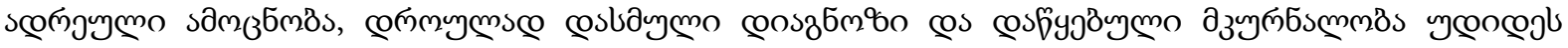

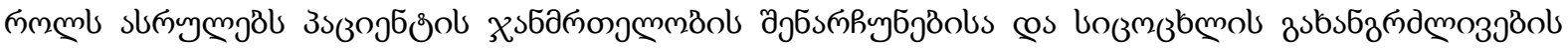

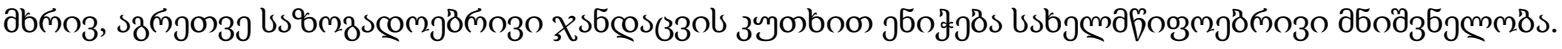

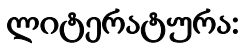

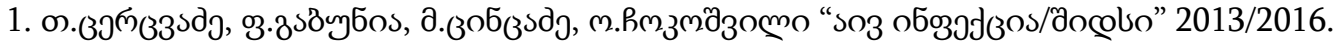

2. Leão JC, Ribeiro CMB, Carvalho AAT, Frezzini C, Porter S. Oral complications of HIV disease. Clinics. 2009; 64(5):459-70.

3. Maeve M. Coogan, John Greenspan, Stephen J. Challacombe"Oral lesions in infection with human immunodeficiency virus" Bull World Health Organ. 2005 Sep;83(9):700-6. Epub 2005 Sep 30. h t t p : //www.ncbi.nlm.nih.gov/pubmed/16211162

4. Hoffman; Rockstroh; HIV 2015; medizinFokusVerlag, HAmburg; www.hivbook.com 
5. http://www.who.int/hiv/en/

6. http://aidscenter.ge/epidsit_world_geo.html

7. Oral lesions in infection with human immunodeficiency virus Maeve M. Coogan,1 John Greenspan,2 \& Stephen J. Challacombe3 Bulletin of the World Health Organization September 2005, 83 (9) p.700-706.

Bukhnikashvili E., Abashidze N., Tsintsadze M., Iverieli M. , Gogishvili Kh.

\section{HIV/AIDS RELATED ORAL MANIFESTATIONS AND THEIR STATISTICS IN GEORGIA 2016}

TSMU, DEPARTMENT OF PERIODONTICS AND ORAL MUCOSA DISORDERS; INFECTIOUS DISEASES, AIDS AND CLINICAL IMMUNOLOGY RESEARCH CENTER; “HBI-DENTIMPLANT” GEORGIAN - GERMAN IMPLANTATION CENTER

The goal of our research was to determine the frequency of oral manifestations among the new revealed HIV-infected persons in 2016. For this we studied the database of the AIDS Center and we explored a certain group of patients with oral manifestations and carried out according to the dental examination. The results are:

In 2016 totally were found out 719 new cases of HIV infections in a various stages: $11(1,53 \% \pm 8,02 \%)$ were Acute stage, $130(18.08 \% \pm 2.12 \%)$-Asymptomatic stage, $361(50,21 \% \pm 0.996 \%)$ - Symptomatic NonAIDS, $214(29,76 \% \pm 1.54 \%)$-AIDS, just $3(0,42 \% 15,4 \%)$ - NonAIDS/unknown state. Among of them HIVassociated oral manifestations were found in 245 (34.07\%1.39\%) patients. We investigated 125 $(51,02 \% 0,97 \%)$ cases and as a result: $69(55.2 \% 0.9 \%)$ were oral candidiasis, $3725,52 \% 1,71 \%)$ manifestati ons were caused by herpes-vi rus. $9(6,21 \% \pm 3,89 \%)$ of them were oral hairy leukoplakia, $8(5,52 \% \pm 4,13 \%)$ gingivitis and periodontitis, Non Hodgkin's lymphoma - just $1(0,14 \% \pm 26,7 \%)$ case and Kaposi’s Sarcoma also $1(0,14 \% \pm 26,7 \%)$ in the year. 